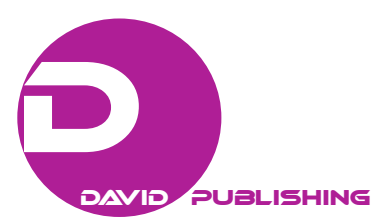

\title{
The Brand Made in Italy: A Critical Analysis
}

\author{
Valerio Temperini, Gian Luca Gregori, Paola Palanga \\ Polytechnic University of Marche, Ancona, Italy
}

\begin{abstract}
Several studies about the brand "made in Italy" have illustrated the real significance of this brand, placing it in the top position for brand awareness in most countries. The words "made in Italy" evoke in consumers' minds attributes that positively characterize the image of Italy as a country-in particular, the attributes of creativity, aesthetics, quality, and sophistication-facilitating the perception of a differential value through the effect of the product-country association. Italians are proud of this, but what really composes the brand "made in Italy"? Above all, is there any truth behind this expression? The paper aims to propose a critical analysis about the "made in Italy" value appropriation and the future development of this brand.
\end{abstract}

Keywords: made in Italy, brand, counterfeiting, hybrid products

\section{Introduction}

This paper starts by highlighting that "made in Italy" is a very complex and multi-faceted concept, as it can be defined in several ways according to different perspectives (legal, the firm's perspective, the consumer's point of view, there are numerous definitions).

The first question that poses a challenge to answer is "which sectors does the 'made in Italy' brand include". Generally, academicians tend to focus attention on traditional productive sectors for which indeed the value of the brand is superior. In particular, it can be listed as appealing to some sectors, such as food, fashion, furniture, and design, whose products have gained a certain uniqueness strongly associated with the image of Italy. Information about the origin of these products has a greater effect than those recognized in other product categories. It is a principle widely discussed in literature (Roth \& Romeo, 1992; Liefeld, 2004; Hamzaoui \& Merunka, 2006), confirmed also by Aiello, Donvito, Grazzini, and Mazzoli (2014) in a recent empirical study.

This should not lead one to overlook the fact that the "made in Italy" brand constitutes a relevant element also for other production sectors, which, in turn, contributes to its recognition and leads consumers to perceive it in a positive way throughout the world. For further analysis, it can also include the jewelry sector, the musical instrument sector, and the "living" industry, but one might ask why sectors, such as textile machinery and footwear, are excluded, as are culture and tourism.

Therefore, this brand clearly represents a multi-sector composition, characterized by many factors (e.g., types of products and services).

Valerio Temperini, assistant professor of services marketing, Department of Management, Polytechnic University of Marche, Ancona, Italy.

Gian Luca Gregori, professor of business management, Department of Management, Polytechnic University of Marche, Ancona, Italy.

Paola Palanga, Ph.D. student, Department of Management, Polytechnic University of Marche, Ancona, Italy.

Correspondence concerning this article should be addressed to Valerio Temperini, Facoltà di Economia "G. Fuà", Piazzale Martelli 8, 60121, Ancona, Italy. 
The "made in Italy" brand has mainly become synonymous with high production competences, providing added value to the Italian production system, and, from this perspective, it takes the form of a collective asset, a heritage of great value that the Italian industry has inherited. In fact, it is important to note that the brand "has not been created by the current generation", in terms of both cultural heritage and manufacturing. Yet, today, "all those who want to" are able to use it (especially and unfortunately in improper form); it has become a "zero-cost" brand, as a kind of "revenue of a position". But used in this way, the brand cannot thrive, especially in the long run.

The main objective of this work is to analyze the concept of value of the "made in Italy" brand, with particular attention to its appropriation. It can be argued that the issue under study is approached with certain superficiality. The "made in Italy" brand presents a true advantage.

Several studies underline that the outlook for this brand is particularly positive all over the world (Confindustria Prometeia, 2014), for example, considering the evolution of the income per capita in certain geographical areas and therefore the evolution of the number of wealthy, it is plausible to make predictions about the significant potential growth of the exports of Italian products in these areas. In such a context, several questions arise:

- Is "made in Italy" still relevant and significant for all industries and all products?

- Is it defended properly? Or is it taking unreasonable risks?

- How much does the "made in Italy" brand really matter?

Then, the following aspects must be taken into consideration.

It should be stressed that many foreign groups have acquired consolidated Italian brands (known and associated with the "made in Italy" concept), but do they continue to be "made in Italy"? Do they continue to be perceived as such?

There is also the case of Italian companies (especially the fashion industry) that have adopted brands using foreign words (in order to promote the internationalization process).

For further consideration, the textiles and clothing production from the Prato area is made entirely in Italy by Chinese entrepreneurs. Can it still be called "made in Italy", not considering the Italian localization - that is obvious - but taking into account the Italian style and culture which distinguish these productions?

Also, an improper use (counterfeiting, misleading mentions) of this brand can be noted. The result is a downward trend in quality and therefore cost, taking advantage of the same geographical origin (or, at least, making it feel as such). There is no effective protection of the quality and therefore of the brand; in this regard, a well-known aspect and source of concern for its effects lies in the "Italian sounding" in the food industry.

The question arises regarding the real extent of the "made in Italy" heritage as well as its future prospects in light of the effects of these behaviors defined as "prodigal".

\section{Counterfeiting and Italian Sounding}

Counterfeiting refers to the unauthorized representation of a registered brand for the commercialization of non-original products (Retrieved from https://www.wto.org/english/thewto_e/glossary_e/glossary_e.htm). ${ }^{1}$

\footnotetext{
1 The World Trade Organization defines counterfeiting as such: "Unauthorized representation of a registered trademark carried on goods identical or similar to goods for which the trademark is registered, with a view to deceiving the purchaser into believing that he/she is buying the original goods".

A broader concept of counterfeiting also incorporates the unauthorized reproduction of products protected by copyrights and patents; among the negative effects is evident the discouragement to invest in research and innovation, given the risks of inadequate remuneration.
} 
Counterfeiting is a growing phenomenon undergoing an important evolution. As noted by Wilcock and Boys (2014), in the past, relatively small companies characterized the industry of counterfeit products, while during the last 10 to 15 years, the industry has radically changed: The phenomenon has gone from being located in little shops to a sophisticated, large-sized, and well-organized network with international distribution channels. The categories of imitated products have expanded considerably, including medicines, medical equipment, automotive parts, and even aircraft parts; in terms of sales channels, the role of the web should be noted, which has encouraged the expansion of the forgery market, making it also more difficult to contain (Berman, 2008).

This problem notoriously afflicts different stakeholders:

- Consumers are unaware of the purchase of non-original products that appear to be inferior in quality and potentially risky to health;

- Companies with registered brands are obviously damaged, both for lower revenues and for the image damage that results in; the financial resources dedicated to the protection and monitoring of the brand must also be taken into account, which are diverted from the investment in business development;

- Counterfeiting alters the functioning of the market because of unfair competition that also puts the competitiveness of legitimate businesses at risk;

- The practice results in lost tax revenues for states;

- It should also be condemned from the ethical-social point of view, since the producers of counterfeit goods usually do not respect the laws and often employ underpaid employees who work in unbearable and unsafe conditions; the possible exploitation of child labor should also be noted;

- The opportunity for obtaining relatively high profits (compared to initial investments with limited risk), the difficulty of identifying and punishing those responsible (as production and sales are usually made in different countries) (Zimmerman, 2013) ${ }^{2}$, sentences that appear relatively mild justify the interest of organized crime, which has assumed a prominent role in this area (Wilcock \& Boys, 2014). ${ }^{3}$

For the above-mentioned reasons, in accordance with Pastore and Cesareo (2014), counterfeiting must be considered as a negative phenomenon, although someone (especially in relation to the fashion industry) can see the positive aspects. ${ }^{4}$

According to estimates from the International Chamber of Commerce (in 1985 it established the Counterfeiting Intelligence Bureau and in 2004 launched the Business Action to Stop Counterfeiting and Piracy), counterfeiting and "piracy" (this second term refers to copyright infringement) are presently developing a turnover of about 1,000 billion dollars a year and are stealing 2.5 million jobs. Estimates of the weight on the global trade value oscillate between $7 \%$ and $10 \%$.

"Made in Italy" and its most representative brands are among the most affected, especially the fashion sector and the food sector.

The last UIBM report (2014a) highlights that, during the period of 2008 to 2013, about 334 million counterfeit goods were withdrawn for an estimated market value (based on the quality of the counterfeits and

\footnotetext{
${ }^{2}$ Among the major countries producers of counterfeit products, China is the main player at the international level. The protection of industrial property in this country is attracting more attention and some measures have been taken under the pressure from foreign governments. However, this illegal activity is still relevant.

3 This makes the problem more difficult to combat and much more worrisome, considering the fact that these resources nourish other business crimes (arms trafficking, drugs, etc.).

${ }^{4}$ Some believed that being among the counterfeit brands is a sort of recognition of the brand value itself and that the company can gain a contribution through the increase of its prestige. Counterfeiting could also be seen as a benefit to the spread of the brand reputation (especially for "young" brands).
} 
feedback from the market) of about 3.8 billions of euros, excluding food, beverages, tobacco, and drugs. ${ }^{5}$ Among the most reproduced goods were clothing products, accessories, and footwear. Also during the period considered, 75 million pieces were withdrawn for violations of the "made in Italy" regulation.

Counterfeiting has reached considerable dimensions also in the food industry, which constitutes one of the most important sectors of the Italian economy (UIBM, 2014b, p. 2). ${ }^{6}$ In this context, one must emphasize the phenomenon known as "Italian sounding", which refers to the sales of products that sound like they are Italian, but that in fact are not (Table 1). The intent is to evoke Italian country and style to take advantage of the greater appeal that they exert on consumers, in particular foreign ones, who can be more easily misled. This technique can be defined as a form of "identity theft", which, unfortunately, is legalized; indeed, even the EU legislation does not allow counteracting this form of unfair competition. Therefore, Italians assist the helpless to the considerable economic damage to the food sector. To prove this effect, it is enough to say that the market share of "Italian sounding" detraction from the Italian industry each year is globally estimated at around 60 billion euros, equal to double the Italian export of food products.

Table 1

\section{Characteristics of Italian Sounding}

The expression "Italian sounding" refers to a phenomenon of forgery that is particularly diffused in the food industry. It consists in selling products that do not originate in Italy, communicating elements that represent or evoke Italy (e.g., the flag colors, names, expressions, logos, slogans, cities and regions, typical Italian images, imitation DOP notes, DOC, and IGP). It is a practice perpetrated by foreign companies (but also partly by Italian companies) that seek to give products a false Italian identity in order to capitalize on the popularity and the excellent reputation of the Italian culinary tradition. The consumer is induced to think that he/she is buying an authentic Italian product, but it turns out to have inferior quality and is not always safe for health.

Source: Camera di Commercio Italiana per la Romania (2014).

Given the extent reached by the counterfeiting industry and in view of negative consequences that it entails, it is considered as a priority to strengthen efforts to counteract it. This means intervening along the supply chain: producers, distributors, and consumers (Berman, 2008; Zimmerman, 2013; Pastore \& Cesareo, 2014; Wilcock \& Boys, 2014).

First, it is necessary to promote collaboration and coordination among international government authorities to make actions more incisive. It is clear that, in some countries - most notably China (the leading producer of counterfeit goods) - the forgery industry is particularly flourishing; it is also widely known that there are countries that are specifically involved in the distribution of counterfeit goods in order to obscure the Asian origin (Zimmerman, 2013). In this regard, greater international cooperation is desirable in order to promote more stringent laws (with harsher penalties), the tightening of controls, and the identification of those responsible.

Another important effort to inhibit the commercialization of counterfeit goods is the development of technical and technological solutions (RFID, optical code reading, holograms, DNA, etc.), to help ensure the authenticity and traceability of the products; these solutions can help control both activities and consumers in the recognition of original goods.

\footnotetext{
5 The report is based on data about requisitions by the Italian Finance Police and by the Customs Agency.

6 The activities aiming to manipulate the properties of the products as altering, adulteration, sophistication, and replacement of a food with another (e.g., seed oil instead of olive oil) generally comprise the types of counterfeit food and beverages. It includes the "counterfeiting/forgery of the trademark or indication of geographical origin or the designation of origin: The falsification of protected geographical indications and protected designations is a counterfeit that leverages quality, appreciation, and awareness of Italian food products. This phenomenon is known as food piracy or illicit attribution to a food of the designation of another food known for its organoleptic characteristics and/or security or origin, while being different".
} 
Moreover, it is considered important to realize information and education activities for customers. It should be stressed that there are two main segments of customers, consisting respectively of those who are aware that they are buying non-original products and those who are unaware.

With regard to the first segment, various studies have shown that consumers are characterized by a positive attitude towards the purchase of counterfeit goods, mainly justified by the cost effectiveness (hedonism, self-esteem, gratification, and greater heartedness of its use can come into play). This segment appears difficult to quantify, because the respondents should admit to carrying out an illegal or at least ethically improper action. The consumer tendency to purchase fake products may be limited, influencing their attitude through actions to inform and raise awareness of the negative effects related to the phenomenon. Some examples of actions could be the circulation of information about the risks to the health of consumers, the exploitation of child labor, organized crime, and the damage to the economy of the country (Pepe \& Giannini, 2010; UIBM-Censis, 2014). However, studies confirm that even knowing about the contribution to illegal and socially negative activities, several subjects are still likely to buy non-original products, a "social disengagement" occurring. This is confirmed particularly in the case of individuals characterized by low levels of income and education (UIBM, 2011; Mattia, 2013).

Exception is made for those who are unaware that they are buying a fake product. In this case, the negative effect of the counterfeit brand can be even stronger, as it would lead to distrust by the consumer who feels betrayed. This can result in significant image damage.

It should be noted that, in some cases, fake products are characterized by an "apparent quality"; a common consumer (but also a merchant) could hardly perceive them as fake, especially if he or she has not experienced the original goods. Unfortunately, he or she could also be fooled by shop managers who - in good faith or not—offer counterfeit goods; in the case of Italian sounding, this is the routine, creating a "lawful deception" among customers and allowing companies to steal significant value from other companies of authentic "made in Italy".

\section{The "Made in Chitaly" Phenomenon: The Case of the Prato Industrial District}

Italy is characterized by a widespread presence of notoriously high production competences and expertise, especially in manufacturing. The outstanding qualities and abilities that characterize the Italian labor and craftsmen, along with considerable creative skills, point to the fact that Italy represents a particularly interesting place, especially for the realization of high-quality products. This is proved by the fact that several foreign companies make use of the Italian production system for conducting phases or the entire production process or have invested and opened factories in Italy precisely to take advantage of those qualities (CNEL, 2011). The ability to add value to products through the application of the "made in Italy" brand is evidently a sought-after opportunity.

However, there are cases of productions "made in Italy" with the only aim of capturing a mere regulatory advantage or the ability to use the "made in Italy" brand without sharing and helping to develop the values inherent to the brand itself.

The most emblematic case, in this sense, is given by the Chinese companies in the textile-clothing district in Prato, for which several scientific and academic contributions have already analyzed the issue in both economic and social terms.

The Chinese entrepreneurs in that area have settled since the early 1990s, initially as a subcontractor of the local clothing enterprises (Guercini, 2002), particularly specializing in the binding phase. For local businesses, 
it appeared that the opportunity to compensate the difficulty was in finding on-site labor to devote to particular steps, but also to achieve cost benefits. It was a sort of "outsourcing at home" effort (Ceccagno, 2003).

Over the years, the availability of spaces for production vacated by Italian entrepreneurs due to the crisis has encouraged migration from China. Given the high propensity for the entrepreneurship of Chinese people, it has also dramatically increased the number of Chinese enterprises (in contrast with the Italian ones), proving them to be particularly adept to meet the needs of the "pronto moda" (Chen, 2011). ${ }^{7}$ In addition, an "entrepreneurial leap" occurred in which Chinese enterprises moved from subcontracting to companies able to design models, produce them, and commercialize clothing. Following these developments, the Chinese entrepreneurs in the area have become a dominant reality, acquiring a growing role in the international market (Azzari, 2012).

In the IRPET report (2013), there are some economic estimates related to Chinese entrepreneurship in the province of Prato, despite the difficulties in detecting the real dimensions of the phenomenon in light of the irregularities that permeate it. The first fact to note is that, at the end of 2012, Chinese enterprises in the clothing sector accounted for over $80 \%$ of the total; their share of export value resulted in a predominant percentage (over 90\%). It is highlighted in the fact that there is a "parallel district" not integrated with the local production system (also raw materials are usually imported from China). The territory is "used" as a mere physical place for carrying out production activities (sometimes limited only to the assembly), and none of this has had important positive effects. Given the benefits coming from the opportunity to display the label "made in Italy", actually there are costs for society (Pieraccini, 2008; 2010), such as non-payment of taxes and services, pollution, and social tensions. ${ }^{8}$

Consideration should be given also to the evolution drawn from a recent empirical study conducted by IRPET always in the Prato District. Results show that Chinese entrepreneurs of the second generation are able to realize products of average quality. They no longer sell most of the production to Italian wholesalers and hawkers or Chinese immigrants in Italy and Europe, but also to chain stores with a certain reputation, national, and international, especially in Europe but also in America, South Africa, and the Far East. Some of these companies have started to produce in semi-programmed to larger customers. Otherwise, recently they produce in part with their own brand. Other business owners, in order to differentiate themselves, offer "pronto moda" for men instead of women, and they aim at the average consumer, focusing on the content and style of communication, online and offline (IRPET, 2015).

It would seem therefore that Chinese companies, taking advantage also of the Italian location, are able to gain increasingly important market share. Beyond both subjective judgments about the product quality and the economic impact (not easy to estimate) for the Prato area related to the development of these companies, this paper still needs to point out that even in this case, the consumer can be deceived and led to a wrong perception of the value connected to the purchased goods (also considering symbolic and experiential value). The risk is that consumer expectations about the values that properly distinguish the real "made in Italy" brand can be

\footnotetext{
7 The strong propensity for entrepreneurship of the Chinese community in Italy has an emblematic case within the province of Prato. This highlights that unlike other countries, the decision to migrate among Chinese people binds tightly to the entrepreneurial spirit rather than employment. This trend means that it is precisely the size of the business to attract new flows and not vice versa and represents the first rung of the ladder of integration.

${ }^{8}$ A more recent report published by IRPET (2015) emphasized the opportunity of integration for Chinese people with the Prato area. It reports some data on local consumption from the Chinese community and highlights some evidence (albeit very limited) about openness as the request for services by some companies.
} 
disregarded. The latter is in fact distorted, lacking the qualities that it actually represents and that -as mentioned above - are based on the ability of Italian workers and artisans.

Considering the fact that this is a legal appropriation of the "made in Italy" value, one wonders, though, what might be the effect that in the long-term foreign production companies, such as the one established in the Prato may have on the brand itself.

\section{The Italian Brands Acquisition by Foreign Groups}

Regarding the "made in Italy" value appropriation, it seems appropriate to consider also the acquisition by international groups of companies with Italian brand that, in some cases, turn out to be also quite well-known and prestigious; the phenomenon has seen a growing trend in recent years and has involved various production sectors. It is clear, in fact, that the high manufacturing expertise and limited capitalization make Italian companies particularly "attractive".

Loss of command on brand ambassadors of "made in Italy" is at the center of a growing debate focused on opportunities and threats that would follow.

On one hand, foreign investments are deemed necessary for the development of Italian businesses, enabling them to meet the challenges and opportunities posed by the global market. In some situations, they may also provide a solution to overcome financial difficulties driven or exacerbated by the recent economic crisis. In this sense, they are evaluated in a positive view for the safeguarding and development of employment and technical expertise in the Italian country and they are welcomed as supporting "made in Italy". In this perspective, it would be interesting to investigate the performance of such firms acquired by foreign groups (Barbaresco, Maggiore, Matarazzo, \& Resciniti, 2014).

However, another aspect that should be generating deepening concerns is the distribution of value along the supply chain. As it is known, the brand can give significant added value to the company offer (Farquhar, 1989), not only in relation to consumer markets, but also in business-to-business contexts (Michell, King, \& Jeast, 2000; Bendixen, Bukasa, \& Abratt, 2004; Kotler \& Pfoertsch, 2007). The value proposition that companies offer to the market tends to be determined, in fact, not so much from technical-productive activities, but rather by intangible elements that are transmitted precisely by the brand (Park, Jaworksi, \& MacInnis, 1986; Hsieh, 2002). With the sale of the brand, it is therefore likely to cede the opportunity to appropriate the greater part of the value that can be obtained from trade with the market. With regard to acquisitions by foreign companies, therefore, it seems significant to evaluate the relationship between the economic benefits for Italian territory and the profits generated by the effect of "made in Italy" and which would eventually be sent abroad. With the sale of the brand, it is therefore likely to cede the opportunity to appropriate the greater part of the value that can be obtained from trade with markets. With regard to acquisitions by foreign companies, therefore, it seems worthwhile to evaluate the relationship between economic benefits for the Italian country and the profits generated by the "made in Italy" effect, which would eventually be sent abroad.

It should also be emphasized that brands have become a significant power in today's consumer society and their control can afford to exercise a major influence in the economic system. Their transfer in favor of foreign companies is therefore seen alarmingly for the future. This is also because that the attractiveness of a corporate brand is independent from the geographical origin of the product. ${ }^{9}$

\footnotetext{
9 This would be a problem especially in cases in which the acquisition is motivated only by the goal to have a certain brand.
} 
Maintaining the production in the place of origin of the brand might not be important.

Therefore, it is legitimate to ask how foreign investments affect the "made in Italy" perceptions. Moreover, in light of the concerns identified, it should be noted the regret for not having favored policies of integration among Italian companies, avoiding suffering today the actions of international expansion perpetrated by poles of other countries (such as those of the French luxury).

\section{Full Made in Italy and Hybrid Products}

Another interesting topic is the relationship between the corporate brand and the "made in Italy" label. It is clear that the relationship is often of mutual exploitation, in the sense that many companies achieve important results at international level also by being able to boast the "made in Italy" brand, contributing at the same time to increasing its value and prestige on markets.

However, the ongoing globalization process has favored in many cases a weakening of this bond, so much that actually some companies "paladins of the "made in Italy"- driven by increasing price competition - realize production in countries with lower labor costs, but affixing various "made in" and commercializing products using its corporate brand that continues to maintain the Italian spirit. This also happens through communications intended to stimulate associations with the Italian country and to emphasize the characteristics, style, and attention to quality that notoriously connote Italy.

There are also cases of products whose production process is carried out in different countries and that, under the current regulations, boast the label "made in Italy" for the simple fact that the last substantial working is carried out in Italy; opportunistic behavior is thus encouraged at the expense of consumer protection.

The "hybrid" products or those designed in Italy and manufactured abroad are a growing phenomenon given the dynamics of international competition and the opportunity to seize the advantages of production in other areas of the world. These are entrepreneurial choices that could be more or less shared.

The fact is that, as shown in numerous studies (Rosenbloom \& Haefner, 2009; Magnusson \& Westjohn, 2011; Vianelli, Pegan, \& Micoli, 2014), the country of manufacturing (COM) is becoming less important than the country of brand $(\mathrm{COB})$. In this sense, the corporate brand is the most important factor in encouraging buying decisions, becoming the guarantor of the product quality, and satisfying consumer needs based on intangible elements (symbolic, emotional, and experiential). It is, however, questionable whether and until when these brands will continue to be perceived as Italian and to appropriate the value connected to Italian style.

Moreover, what can be done to enhance the Italian production system, given that it was precisely the latter to have developed the intangible elements that make up the "made in Italy" value or the Italian products still associated with this country? This is even in the knowledge that there are market segments in which special attention is paid to products' quality and certain standards can only be achieved with excellent skills spread into the Italian territory (G. X. Li, G. F. Li, \& Kambele, 2012). ${ }^{10}$ This is evidenced by the fact that people are witnessing the so-called reshoring or the return in Italy of productions that in the past have been decentralized or relocated abroad; among the main reasons, there is the higher quality demanded by international clients. ${ }^{11}$

\footnotetext{
${ }^{10}$ With specific reference to the luxury market in China, Li et al. (2012) observed that Chinese consumers of original products are careful to ensure the usefulness of the good and then to the high quality that is guaranteed by the brand, rather than to emotional factors or social prestige.

11 This emerges also from the results of an empirical research conducted by the Department of Management of the Polytechnic University of Marche, which involved 180 manufacturing companies in the Ancona Province.
} 
All of that must therefore be understood as signs for hope, but also factors, such as strong motivation, to invest in the development of the Italian country.

\section{Conclusions}

The cases previously mentioned the obvious impact on the nature and meaning of "made in Italy" and lead us to reflect on the possible impact on its "real value", especially from a future perspective.

There are several works in the literature that analyze the issue of the brand value, noting the elements that contribute to its formation and offering various methods for its measurement, which are divided mainly between financial and customer-related (Aaker, 1991; 1996; Keller, 1993). Among the approaches that favor the customers' perspective, special attention is given to their perceptions (reputation, image, and perceived quality) and related behaviors (loyalty and willingness to recognize a premium price). The customers' point of view is extremely important, as the attributes of a brand are created by its promoter and "manipulated" by the market (Myers, 2003).

In this regard, as already noted, "made in Italy" still definitely enjoys a high degree of awareness in international markets; however, the impact on perceptions, image, and customer loyalty, caused especially by the actions that tend to create confusion and mislead customers, is to be feared.

In particular, it should be noted that the brand essentially embodies and communicates a promise (Knapp, 2000; Dunn \& Davis, 2004; Kotler \& Pfoertsch, 2007) and that developing the buyer confidence is a priority in order to simplify purchasing decisions and increase his/her loyalty (Delgado-Bellester \& Munuera-Alemán, 2001), thus increasing the value of the brand itself (Ambler, 1997; Delgado-Bellester \& Munuera-Alemán, 2005).

The promise inherent in the "made in Italy" brand is the superior quality of products and the brand has become a guarantee to that effect. Its positive image, however, is likely to be affected because of the different misused experienced, which can encourage consumer experiences that do not meet customer expectations, thus undermining their confidence. The perception as well as the reputation of the brand by customers "betrayed" may then mutate in a negative way.

To preserve and increase in the future, the "made in Italy" brand value is important, therefore, to develop the relationship between the brand and the customer, acting positively on trust, satisfaction, and fidelity (Esch, Langner, Schmitt, \& Geus, 2006). It is therefore necessary to limit the inappropriate and opportunistic behaviors, and support at the same time companies who make the real "made in Italy" brand. This could happen, for example, by acting either directly through financial incentives and tax breaks to companies, both in making the overall production system more competitive and also impacting on services. Companies could thus benefit from a recovery of competitiveness useful to meet the challenge of the global market and to deal in part with competition from those who use the "made in Italy" label unfairly.

This could also facilitate the return of production from abroad (reshoring) and then the return to invest in Italian skills; this would avoid the gap between the Italian character (meaning above all style) and the Italian territory as a location for production, that can still be perceived as a sign of weakness that affects the "made in Italy".

Additional considerations must be made, lastly, for the internationalization of small- and medium-size enterprises, as an increasingly forced path for the survival and development of the same. As it is known, both structural and cultural problems limit the expansion processes of those companies in foreign markets; important 
support can be given through "ad hoc" training projects, but also measures to facilitate networks among businesses in order to achieve critical mass are needed to operate efficiently, effectively, and internationally.

\section{References}

Aaker, D. (1991). Managing brand equity. New York, NY: Macmillan.

Aaker, D. (1996). Measuring brand equity across products and markets. California Management Review, 38(3), 102-120.

Aiello, G., Donvito, R., Grazzini, L., \& Mazzoli, V. (2014). Il rapporto tra marca e "made in" nella valorizzazione dei processi di sviluppo internazionale: Gli esiti di una case analysis relativa a Poltrona Frau. Proceedings from Food Marketing. Mercati, filiere, sostenibilità e strategie di marca, XI Convegno Annuale della Società Italiana di Marketing. Modena, 18-19 September.

Ambler, T. (1997). How much of brand equity is explained by trust? Management Decision, 35(4), 283-292.

Azzari, M. (2012). Dal sottoscala, al distretto, al mercato globale. Il ruolo dell'imprenditoria straniera nell'evoluzione del sistema economico della Piana di Firenze e Prato. Geotema, 21, 43-45.

Barbaresco, G., Maggiore, G., Matarazzo, M., \& Resciniti, R. (2014). Le acquisizioni dall'estero delle medie imprese italiane: Una ricerca per la valutazione delle performance. Proceedings from Food Marketing. Mercati, filiere, sostenibilità e strategie di marca, XI Convegno Annuale della Società Italiana di Marketing. Modena, 18-19 September.

Bendixen, M., Bukasa, K. A., \& Abratt, R. (2004). Brand equity in the business-to-business market. Industrial Marketing Management, 33, 371-380.

Berman, B. (2008). Strategies to detect and reduce counterfeiting activity. Business Horizons, 51, 191-199.

Camera di Commercio Italiana per la Romania. (2014). Report di rilevazione di casi di Italian Sounding nella GDO in Romania. Retrieved from http://www.cameradicommercio.ro/images/stories/Report/Report\%20prodotti\%20italiani\%20GDO_2.pdf

Ceccagno, A. (2003). Migranti a Prato: Il distretto tessile multietnico. Milano: Franco Angeli.

Chen, C. (2011). Made in Italy (by the Chinese): Economic restructuring and the politics of migration. Inter Asia Papers, 20, $1-34$.

CNEL. (2011). Il profilo nazionale degli immigrati imprenditori in Italia. Rapporto di studio. Retrieved from http://www.cnel.it/271?shadow_documento_altri_organismi=3430

Confindustria Prometeia. (2014). Esportare la dolce vita. Roma: SIPI Spa.

Delgado-Bellester, E., \& Munuera-Alemán, J. L. (2001). Brand trust in the context of consumer loyalty. European Journal of Marketing, 35(11-12), 1238-1258.

Delgado-Bellester, E., \& Munuera-Alemán, J. L. (2005). Does brand trust matter to brand equity? Journal of Product \& Brand Management, 14(3), 187-196.

Dunn, M., \& Davis, S. M. (2004). Creating the brand-driven business: It's the CEO who must lead the way? Handbook of Business Strategy, 5(1), 241-245.

Esch, R. F., Langner, T., Schmitt, B. H., \& Geus, P. (2006). Are brands forever? How brand knowledge and relationships affect current and future purchases. Journal of Product \& Brand Management, 15(2), 98-105.

Farquhar, P. (1989). Managing brand equity. Marketing Research, 1, 24-33.

Guercini, S. (2002). Profilo del vertice, processi di sviluppo e politiche di mercato dell'impresa cinese a Prato. In M. Colombi (Ed.), L'imprenditoria cinese nel distretto industriale di Prato (pp. 35-70). Firenze: Olschki.

Hamzaoui, L., \& Merunka, D. (2006). The impact of country of design and country of manufacture on consumer perceptions of bi-national products' quality: An empirical model based on the concept of fit. Journal of Consumer Marketing, 23(3), $145-155$

Hsieh, M. H. (2002). Identifying brand image dimensionality and measuring the degree of brand globalization: A cross-national study. Journal of International Marketing, 10, 46-65.

IRPET. (2013). Prato: Il ruolo economico della comunità cinese, Rapporto di studio e ricerca. Firenze: IRPET.

IRPET. (2015). Relazioni locali e transnazionali delle imprese cinesi di Prato e loro contributo all'economia della provincia, Rapporto di studio e ricerca. Firenze: IRPET.

Keller, K. (1993). Conceptualizing, measuring, and managing customer-based brand equity. Journal of Marketing, 57(January), 1-22.

Knapp, D. E. (2000). The brand mindset. New York, NY: McGraw-Hill.

Kotler, P., \& Pfoertsch, W. (2007). Being known or being one of many: The need for brand management for business to business (B2B) companies. Journal of Business \& Industrial Marketing, 22(6), 357-362. 
Li, G. X., Li, G. F., \& Kambele, Z. (2012). Luxury fashion brand consumers in China: Perceived value, fashion lifestyle, and willingness to pay. Journal of Business Research, 65, 1516-1522.

Liefeld, J. P. (2004). Consumer knowledge and use of country-of-origin information at the point of purchase. Journal of Consumer Behaviour, 4(2), 85-96.

Magnusson, P., \& Westjohn, S. A. (2011). What? I thought Samsung was Japanese: Accurate or not, perceived country of origin matters. International Marketing Review, 28(5), 454-472.

Mattia, G. (2013). Motivazioni e comportamenti nei confronti della contraffazione non-deceptive: Un'indagine esplorativa sui giovani acquirenti. Mercati e Competitività, 2, 83-103.

Michell, P., King, J., \& Jeast, J. (2001). Brand values related to industrial products. Industrial Marketing Management, 30(5), 415-425.

Myers, C. A. (2003). Managing brand equity: A look at the impact of attributes. Journal of Product \& Brand Management, 12(1), $39-51$.

Park, C. W., Jaworksi, B. J., \& MacInnis, D. J. (1986). Strategic brand concept-image management. Journal of Marketing, 50, 135-145.

Pastore, A., \& Cesareo, L. (2014). No al falso! Un'indagine esplorativa sulle strategie anti-contraffazione delle fashion firms. Mercati e Competitività, 2, 81-102.

Pepe, S., \& Giannini, A. M. (2010). Perché si acquistano prodotti contraffatti? Un'analisi esplorativa nel Mezzogiorno d'Italia. Micro \& Macro Marketing, 1, 27-44.

Pieraccini, S. (2008). L'assedio cinese: Il distretto parallelo del pronto moda di Prato. Milano: Il Sole 24 ore.

Pieraccini, S. (2010). L'assedio cinese: Il distretto senza regole degli abiti low cost di Prato (2nd ed.). Milano: Gruppo 24 ore.

Rosenbloom, A., \& Haefner, J. E. (2009). Country-of-origin effects and global brand trust: A first look. Journal of Global Marketing, 22, 267-278.

Roth, M. S., \& Romeo, J. B. (1992). Matching product category and country image perception: A framework for managing country-of-origin effects. Journal of International Business Studies, 23(3), 477-497.

UIBM. (2011). Indagine sulla percezione dei consumatori rispetto alla contraffazione (Dipartimento per l'impresa e l'internazionalizzazione, Direzione Generale per la lotta alla contraffazione-Ufficio Italiano Brevetti e Marchi, Ministero dello Sviluppo Economico, Roma).

UIBM. (2014a). La contraffazione in cifre: La lotta alla contraffazione in Italia negli anni dal 2008 al 2013 (Direzione Generale per la Lotta alla Contraffazione-Ufficio Italiano Brevetti e Marchi, Ministero dello Sviluppo Economico, Roma).

UIBM. (2014b). La lotta alla contraffazione in Italia nel settore agroalimentare 2009-2012 (Direzione Generale per la Lotta alla Contraffazione-Ufficio Italiano Brevetti e Marchi, Ministero dello Sviluppo Economico, Roma).

UIBM-Censis. (2014). La contraffazione: dimensione, caratteristiche ed approfondimenti. Rapporto 2014: La parola ai giovani e al territorio (Direzione Generale per la Lotta alla Contraffazione-Ufficio Italiano Brevetti e Marchi, Ministero dello Sviluppo Economico, Roma).

Vianelli, D., Pegan, G., \& Micoli, C. (2014). Dal country of origin al country of brand: Quali sfide per le imprese del made in Italy? Proceedings from Food Marketing. Mercati, filiere, sostenibilità e strategie di marca, XI Convegno Annuale della Società Italiana di Marketing. Modena, 18-19 September.

Wilcock, A. E., \& Boys, K. A. (2014). Reduce product counterfeiting: An integrated approach. Business Horizons, 57, $279-288$. World Trade Organization. (2015). Glossary. Retrieved from https://www.wto.org/english/thewto_e/glossary_e/glossary_e.htm

Zimmerman, A. (2013). Contending with Chinese counterfeits: Culture, growth, and management responses. Business Horizons, $56,141-148$. 